\title{
Uszkodzenia komór i kolektorów kotłów parowych - badania diagnostyczne
}

\section{Failure of chambers and collectors of steam boilers - diagnostic tests}

\section{Streszczenie}

W artykule przedstawiono przyczyny i objawy uszkodzenia komór i kolektorów parowych. Zaprezentowano stosowane badania diagnostyczne komór kotłów parowych. Przedstawiono częstotliwość i metody badań diagnostycznych. Omówiono sposoby zapobiegania uszkodzeniom. Przedstawiono wymagania rozporządzenia Ministra Gospodarki, Pracy i Polityki Społecznej z 9 lipca 2003 r. w sprawie warunków technicznych dozoru technicznego w zakresie eksploatacji niektórych urządzeń ciśnieniowych w toku eksploatacji.

\section{Wstęp}

Przyczyną zużywania się elementów urządzenia energetycznego podczas długotrwałej eksploatacji jest działanie różnych czynników, takich jak: wysoka temperatura, wysokie ciśnienie, wzrost naprężeń, zmęczenie cieplne materiału, pełzanie (praca $w$ temperaturze wyższej od obliczeniowej), starzenie materiału, erozja, korozja itp. $[1 \div 5]$. Zostały one szczegółowo przedstawione w pierwszej części publikacji [7].

Dlatego niezbędne są badania diagnostyczne i profilaktyczne w szerokim zakresie, które umożliwiają ocenę stanu technicznego urządzeń, wcześniejsze wykrycie i naprawę uszkodzeń lub wymianę zużytych elementów. Badania te zapobiegają również groźnym w skutkach awariom i nieplanowanym postojom urządzeń.

Dr hab. inż. Jacek Słania, prof. PCz - Politechnika Częstochowska, mgr inż. Andrzej Kostańczyk - Urząd Dozoru Technicznego.
Uszkodzenia w komorach ekranowych można wykrywać badaniami magnetyczno-proszkowymi i wizualnie, a w komorach przegrzewaczy - przez badania magnetyczno-proszkowe ultradźwiękowe, badania wizualne z wykorzystaniem endoskopu; prowadzi się również pomiary owalizacji otworów oraz pomiary strzałki ugięcia komór. Zależnie od otrzymanych wyników określa się okres specjalnego nadzoru, w którym prowadzone są specjalistyczne badania stanu technicznego komór.

\section{Badania diagnostyczne komór kotłów parowych}

Podczas okresowych badań diagnostycznych komór w wielu miejscach na powierzchni zewnętrznej, a szczególnie wewnętrznej, są wykrywane pęknięcia. Pęknięcia te $z$ reguły wypełnione są tlenkami i mają charakter śródkrystaliczny. Wewnątrz pęknięć znajdują się wysepki wolnego metalu. Ten proces niszczenia nosi nazwę zmęczenia korozyjnego i zachodzi 
w przypadku jednoczesnego działania naprężeń zmiennych przekraczających granicę plastyczności i czynnika agresywnego. Czynnikiem agresywnym może być woda kotłowa, para wodna i kondensat. W miejscu powstałego pęknięcia zmęczeniowego niechroniony metal podlega korozji elektrochemicznej. Powstające produkty korozji wytwarzają warstwę ochronną, która ulega jednak uszkodzeniu pod wpływem działania naprężeń zmiennych, przekraczających jej wytrzymałość. Naprzemienne działanie tych dwóch procesów powoduje w niej uszkodzenia, które można podzielić na trzy grupy:

- powodujące natychmiastową wymianę elementu $(10 \%)$,

- wymagające natychmiastowej naprawy (40\%),

- nadające się do naprawy podczas najbliższego remontu.

Większość uszkodzeń komór wykrywa się w czasie okresowych badań diagnostycznych. Przeważająca liczba uszkodzeń spowodowana jest pęknięciami:

- krawędzi i otworów oraz mostków międzyotworowych,

- spoin pachwinowych króćców,

- spoin obwodowych denek.

Do uszkodzenia może też dojść wskutek:

- cyklicznie nagromadzonego odkształcenia w wyniku sumowania się naprężeń. Zniszczenia w postaci pęknięć równoległych do osi komory umiejscowione są na krawędziach otworów i na mostkach międzyotworowych;

- cyklicznie nagromadzonego odkształcenia na krawędziach otworów;

- cyklicznego odkształcenia sprężystego lub plastycznego na dolnych tworzących komory. Uszkodzenie z reguły ma postać trwałego ugięcia komory. Grubości ścianek komór liczone są z uwzględnieniem naprężeń obwodowych i granicy plastyczności w podwyższonej temperaturze $\left(R_{\text {eto }}\right)$ lub wytrzymałości czasowej $\left(\mathrm{R}_{\mathrm{zto}}\right)$.

Dane literaturowe oraz doświadczenia zebrane w krajowej energetyce potwierdzają, że bez względu na przepracowaną przez komory liczbę godzin wpływ na powstawanie uszkodzeń spowodowanych zmęczeniem wytrzymałościowym lub małocyklicznym wywołanym nadmiernymi szybkościami zmian temperatury ścianki metalu w stanach nieustalonych występuje bardzo rzadko. Przyczyną powstawania naprężeń zmiennych powodujących uszkodzenia są $z$ reguły termoszoki (udary cieplne będące przyczyną nagrzewania, schładzania przy nagłej zmianie temperatury czynnika). Udar cieplny występuje wówczas, gdy współczynnik przejmowania ciepła między czynnikiem a elementem $\alpha \rightarrow \infty$, bo wtedy ogrzewane - schładzane włókna ścianki elementu szybko osiągają temperaturę czynnika, zanim dalsze warstwy ścianki zdążą zmienić swą temperaturę. W ten sposób w ściance powstają naprężenia cieplne mogące przekraczać znacznie granicę plastyczności metalu $\left(R_{e t}\right)$, a szczególnie warstwy ochronnej. Przyczyną powstawania termoszoków w komorach z reguły jest kontakt metalu z czynnikiem, którego temperatura znacznie różni się od temperatury ścianki.

\section{Termoszoki}

Poniżej omówiono głowne przyczyny ich powstawania:

1) Gromadzenie się schłodzonego kondensatu w wężownicach, który przy uruchomieniu kotła ze stanu gorącego wraz ze wzrostem ciśnienia wtłaczany jest do komory, co znacznie ochładza jej dolną część, a szczególnie krawędzie otworów (pęknięcie podłużne, rys. 1).

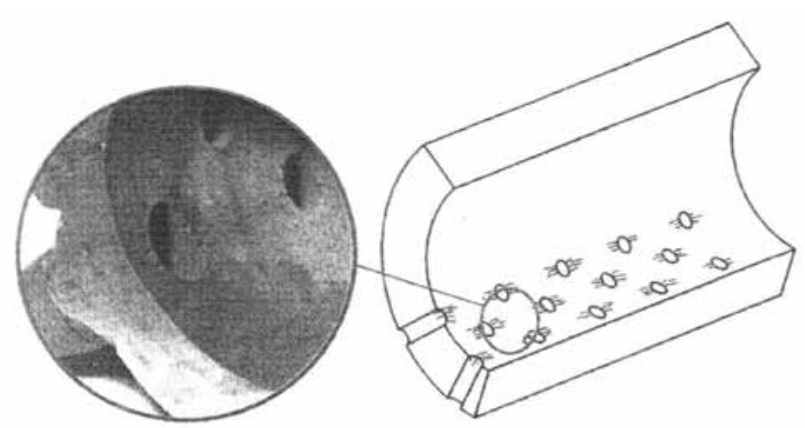

Rys. 1. Komory przegrzewaczy ekranów podgrzewaczy wody. Pęknięcia podłużne przy krawędziach otworów [8]

Fig. 1. Chambers of water superheaters' screens. Longitudinal cracks by the edges of inlets [8]

2) Niewłaściwa konstrukcja komory, zbyt mała grubość mostków obwodowych, co powoduje wzrost naprężeń osiowych wywołanych szybkimi zmianami temperatury w stosunku do pozostałych części komory (pęknięcia mostków obwodowych, rys. 2).

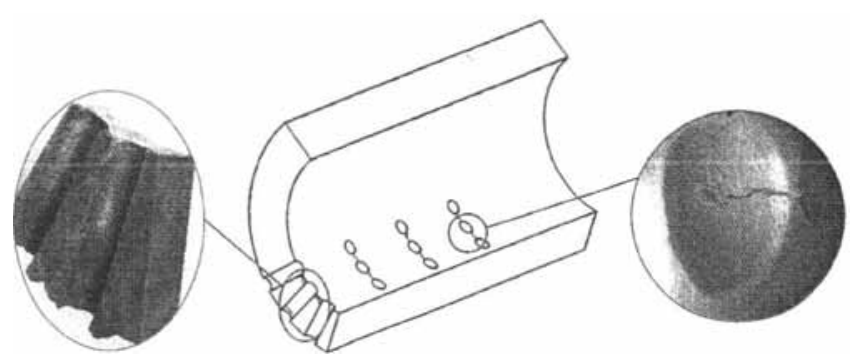

Rys. 2. Grubościenne komory przegrzewaczy. Pęknięcie obwodowe na mostkach komory przegrzewaczy [8]

Fig. 2. Thick-walled chambers of superheaters. Circuital cracks at the bridges of the superheaters' chamber [8]

3) Gromadzenie się kondensatu na dolnych tworzących komory, a szczególnie przy dnach oraz miejscach zmiany średnicy wewnętrznej, np. przy spoinach obwodowych (deformacje i pęknięcia spoin denek - rys. 3 oraz siatka pęknięć w miejscach zmiany średnic - rys. 4). 


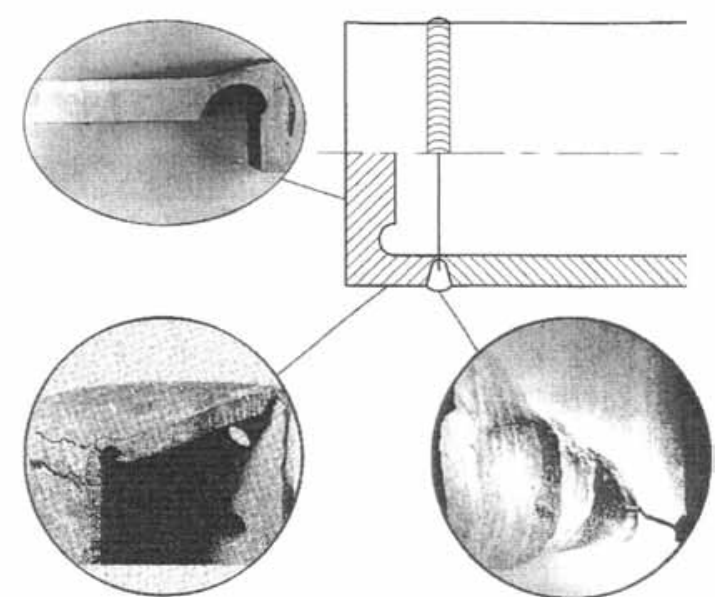

Rys. 3. Dna komór cienkościennych. Pęknięcia denek i spoin [8] Fig. 3. The areas of bottoms of thin-walled chambers. The bottoms and the welds cracks [8]

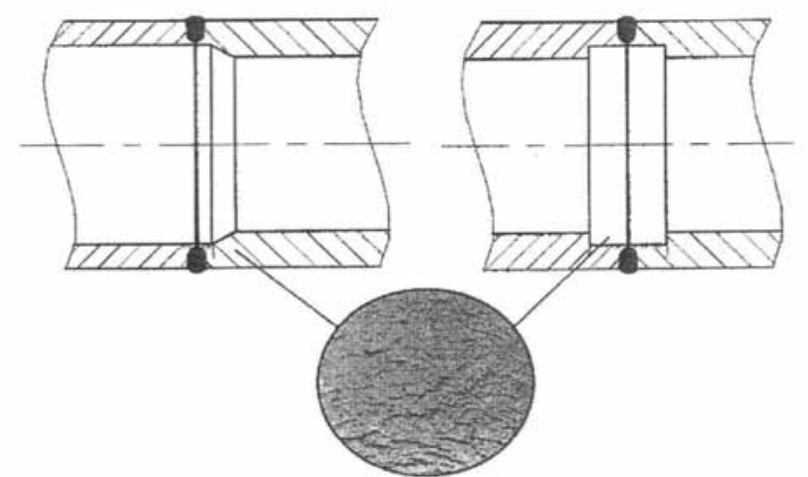

Rys. 4. Komory przegrzewaczy. Siatka pęknięć w miejscach zmiany średnic [8]

Fig. 4. The chambers of superheaters. The net of cracks in the areas of the diameter change [8]

4) Gromadzenie się kondensatu w rurociągach pracujących okresowo (odwodnienia, odpowietrzenia, pomiar ciśnienia), który przy spadku ciśnienia (wzrost obciążenia) jest wsysany do komory i schładza krawędzie otworów (pęknięcia promieniowe na krawędziach otworów, rys. 5).

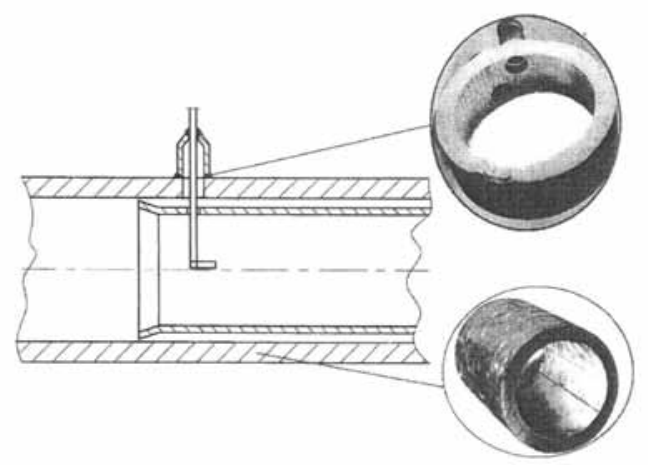

Rys. 5. Komory przegrzewaczy schładzacza. Krawędzie przewodów pracujących okresowo (odwodnienia-odpowietrzenia itp.). Pęknięcia promieniowe [8]

Fig. 5. The chambers of superheaters' attemperator. The edges of pipes working periodically (dehydration, air release etc.). Radial cracks [8]
5) Nagła zmiana wydajności kotła powodująca duży wzrost ilości ciepła doprowadzanego do kotła i nienadążająca za nim prędkość przepływu czynnika przy ponownym spadku obciążenia, co wywołuje schładzanie dolnej części komory (pęknięcia wzdłużne w dolnej części komory).

6) Wykonywanie próby ciśnieniowej po naprawach doraźnych na niewystudzonym kotle, co wywołuje schłodzenie krawędzi otworów/wężownic i rurociągów komunikacyjnych (pęknięcia wzdłużne w pobliżu otworów).

7) Niesprawność schładzaczy wtryskowych lub ich praca na maksymalnej wydajności przy niskich wydajnościach kotła, co powoduje schładzanie ścianek które komór - przenoszenie kropelek wody (siatka pęknięć - rys. 6).

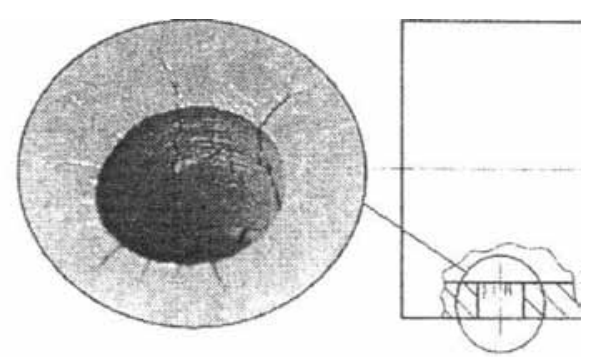

Rys. 6. Schładzacze wtryskowe. Pęknięcia podłużne w strefie niesprawnej dyszy wtryskowej [8]

Fig. 6. Injection attemperators. Longitudial cracks in the areas of the failure injection nozzle [8]

8) Uruchamianie kotła na pełnej wydajności zaworów regulacyjnych na rurociągach wody zasilającej, które powoduje schładzanie ścianek komór wlotowych podgrzewacza wody (pęknięcia podłużne w pobliżu otworów).

9) Powrót kondensatu z rurociągów - przewodów pracujących okresowo (pęknięcia promieniowe na krawędzi otworów, rys. 5).

Tablica I. Zalecana częstotliwość i metody badań diagnostycznych [5]

Table I. Recommended methods and the frequency of diagnostic testskomór kotłów parowych [5]

\begin{tabular}{|c|c|c|}
\hline \multicolumn{2}{|c|}{ Typ badania } & Czas wykonywania badań \\
\hline \multicolumn{2}{|c|}{$\begin{array}{l}\text { Przegląd powierzchni } \\
\text { wewnętrznej }\end{array}$} & $\begin{array}{c}\text { po każdych przepracowanych } \\
\text { max. } 50000 \mathrm{~h}\end{array}$ \\
\hline \multicolumn{2}{|c|}{$\begin{array}{l}\text { Badania fluoromagnetyczne } \\
\text { spoin głównych i kątowych }\end{array}$} & $\begin{array}{l}\text { po } 100000 \mathrm{~h} \text {, a następnie } \\
\text { każdych max. } 50000 \mathrm{~h}\end{array}$ \\
\hline \multicolumn{2}{|c|}{$\begin{array}{l}\text { Ultradźwiękowe pomiary } \\
\text { grubości ścianki }\end{array}$} & jednorazowo \\
\hline $\begin{array}{l}\text { Pomiary } \\
\text { ugięcia }\end{array}$ & \multirow{3}{*}{$\begin{array}{c}\text { dotyczy komór } \\
\text { pracujących } \\
\text { powyżej } \\
\text { temperatury } \\
\text { granicznej }\end{array}$} & $\begin{array}{l}\text { po każdych przepracowanych } \\
\text { max. } 50000 \mathrm{~h}\end{array}$ \\
\hline $\begin{array}{l}\text { Repliki i pomia- } \\
\text { ry twardości }\end{array}$ & & $\begin{array}{l}\text { po } 100000 \mathrm{~h} \text {, a następnie } \\
\text { każdych max. } 50000 \mathrm{~h}\end{array}$ \\
\hline $\begin{array}{l}\text { Pomiary } \\
\text { odkształceń } \\
\text { średnicy }\end{array}$ & & $\begin{array}{c}\text { po każdych przepracowanych } \\
\text { max. } 50000 \mathrm{~h}\end{array}$ \\
\hline
\end{tabular}


Jak już wspomniano, w większości przypadków wszystkie wykrywane nieciągłości są spowodowane zmęczeniem korozyjnym.

Aby uniknąć powstania nieszczelności, omawiane komory powinny być poddawane okresowym badaniom nieniszczącym. Typowy zakres i częstotliwość badań diagnostycznych komór podano w tablicy I, a podstawowe przyczyny i objawy uszkodzeń komór w tablicy II.

\section{Zapobieganie uszkodzeniom kotła}

- Unikać nagłych zmian wydajności kotła.

- Na rurociągach pracujących okresowo (odwodnienie itp.) wszelkie zamknięcia zabudowywać jak najbliżej komory,
- Króćce odpowietrzeń oraz do pomiaru ciśnienia wykonać w postaci tzw. kielichowej z wewnętrzną osłonę chroniącą otwór komory przed nagłym schłodzeniem,

- W miarę możliwości wymienniki regeneracyjne włączać już we wczesnej fazie obciążenia bloku.

- Podczas dłuższych postojów bloku stosować konserwację całego układu wodno-parowego kotła.

- Odkształcone komory w miejscach maksymalnego ugięcia zaopatrzyć w dodatkowe odwodnienia lub w miarę możliwości prostować je.

Trzeba też wykonywać okresowe badania diagnostyczne pozwalające na dokonanie oceny stanu badanych elementów oraz zachodzących w nich procesów zniszczenia [5].

Tablica II. Podstawowe przyczyny i objawy uszkodzeń komór [5]

Table II. The basic causes and symptoms of the chambers' failure [5]

\begin{tabular}{|c|c|c|c|c|}
\hline Komora & Miejsce uszkodzenia & Objawy uszkodzenia & Przyczyny uszkodzenia & $\begin{array}{c}\text { Prawdopodobieństwo } \\
\text { uszkodzenia }\end{array}$ \\
\hline $\begin{array}{l}\text { Podgrzewacz wody } \\
\text { komora wlotowa }\end{array}$ & $\begin{array}{l}\text { krawędzie otworów } \\
\text { od wewnątrz }\end{array}$ & pęknięcia promieniowe & niska temp. wody zasilającej & średnie \\
\hline $\begin{array}{c}\text { Parownik } \\
\text { komory wlotowe }\end{array}$ & $\begin{array}{c}\text { krawędzie otworów } \\
\text { od zewnątrz }\end{array}$ & pęknięcia promieniowe & $\begin{array}{c}\text { termoszok, niska temp. wody przy napeł- } \\
\text { nianiu do próby wodnej }\end{array}$ & małe \\
\hline \multirow{4}{*}{$\begin{array}{l}\text { Przegrzewacz } \\
\text { komory wlotowe } \\
\text { i wylotowe }\end{array}$} & \multirow{2}{*}{$\begin{array}{l}\text { krawędzie otworów } \\
\text { od wężownic }\end{array}$} & pęknięcia podłużne & wahanie obciążenia kotła & średnie \\
\hline & & pęknięcia obwodowe & niewłaściwa konstrukcja & małe \\
\hline & $\begin{array}{c}\text { krawędzie otworów } \\
\text { odwodnień, odpowie- } \\
\text { trzeń, pomiaru ciśnienia }\end{array}$ & pęknięcia promieniowe & $\begin{array}{c}\text { powrót kondensatu z rurociągów, } \\
\text { wtłaczanie zimnego kondensatu } \\
\text { z wężownic do komór, uruchamianie } \\
\text { ze stanu gorącego }\end{array}$ & duże \\
\hline & króćce, spoiny, dna & pęknięcia obwodowe & $\begin{array}{c}\text { dodatkowy moment zginający, zmiana } \\
\text { wydłużenia cieplnego }\end{array}$ & małe \\
\hline Schładzacze wtryskowe & $\begin{array}{l}\text { ścianka wewnętrzna } \\
\text { w pobliżu dysz }\end{array}$ & siatka pęknięć & niesprawne urządzenie wtryskowe & średnie \\
\hline
\end{tabular}

\section{Podsumowanie}

Do najbardziej krytycznych elementów kotła należą komory, a w nich najczęściej ulegają uszkodzeniom wylotowe komory przegrzewaczy pary świeżej i wtórnie przegrzanej.

Przyczyny i objawy uszkodzeń zestawiono w tablicy II. Opisane tam procesy mogą prowadzić do pęknięć, odkształceń otworów i średnicy komory, ubytków grubości czy ugięcia komory. Niezbędna jest zatem okresowa kontrola i sprawdzenie stanu technicznego kotłów i komór. Według rozporządzenia Ministra Gospodarki, Pracy i Polityki Społecznej z 9 lipca 2003 r. w sprawie warunków technicznych dozoru technicznego w zakresie eksploatacji niektórych urządzeń ciśnieniowych w czasie eksploatacji przeprowadza się następujące badania techniczne: rewizje wewnętrzne, próby ciśnieniowe, rewizje zewnętrzne.

Rewizja wewnętrzna obejmuje ocenę wizualną stanu ścianek urządzenia ciśnieniowego, jego połączeń rozłącznych i nierozłącznych oraz osprzętu zabezpieczającego i ciśnieniowego.
W technicznie uzasadnionych przypadkach ocena wizualna może być uzupełniona innymi badaniami. W rozporządzeniu tym są również określone wymagania co do rewizji wewnętrznych komór:

Komory o średnicy większej niż 160 mm kotłów parowych o wydajności pary nie mniejszej niż $100 \mathrm{t} / \mathrm{h}$ poddaje się rewizji wewnętrznej nie rzadziej niż co:

1) 10 lat - w przypadku temperatury dopuszczalnej $\mathrm{T}_{\mathrm{D}} \geq+500^{\circ} \mathrm{C}$

2) 15 lat - w przypadku temperatury dopuszczalnej $+350^{\circ} \mathrm{C} \leq \mathrm{T}_{\mathrm{D}}<+500^{\circ} \mathrm{C}$

3) 20 lat $-w$ przypadku temperatury dopuszczalnej $\mathrm{T}_{\mathrm{D}}<+350^{\circ} \mathrm{C}$.

Terminy badań określone $\mathrm{w}$ rozporządzeniu są terminami minimalnymi i dlatego w celu utrzymania wysokiej niezawodności kotłów zalecane jest prowadzenie okresowych badań diagnostycznych z wykorzystaniem badań nieniszczących, które umożliwiają dokładniejszą ocenę stanu technicznego, w wyniku czego otrzymamy możliwość monitorowania procesów niszczenia, które zachodzą w komorach [6]. 


\section{Literatura}

[1] Hernas A., Dobrzyński J.: Trwałość i niszczenie elementów kotłów i turbin parowych. Wydawnictwo Politechniki Śląskiej, 2003.

[2] Dobosiewicz J., Zbroińska-Szczechura E.: Uszkodzenie komór przegrzewaczy kotłów parowych - Energetyka - nr 3, 1993.

[3] Dobosiewicz J.: Ugięcie komór parowych - Energetyka - nr 10, 1995.

[4] Zbroińska-Szczechura E.: Uszkodzenia płaskich den komór z rowkami odciążającymi przegrzewaczy kotłów. - Energetyka $-\mathrm{nr}$ 6, 2005.

[5] Zbroińska-Szczechura E., Dobosiewicz J.: Badania diagnostyczne komór kotłów parowych - Dozór Techniczny - nr 2, 2004.
[6] Rozporządzenie Ministra Gospodarki, Pracy i Polityki Społecznej z dnia 9 lipca 2003 r. w sprawie warunków technicznych dozoru technicznego w zakresie eksploatacji niektórych urządzeń ciśnieniowych.

[7] Słania J., Kostańczyk A.: Uszkodzenia komór i kolektorów kotłów parowych - przyczyny powstawania. Przegląd Spawalnictwa (publikacja złożona do druku).

[8] Dobosiewicz J.: Ocena ryzyka niezawodnej eksploatacji komór przegrzewaczy kotłów parowych - Dozór Techniczny $-\mathrm{nr} 3,2009$

\section{Dolnośląska Sekcja Spawalnicza SIMP \\ Zakład Spawalnictwa Instytutu Technologii Maszyn i Automatyzacji i Wydział Mechaniczny Politechniki Wrocławskiej}

\section{zapraszają do udziału \\ w 4. Międzynarodowej Konferencji Naukowo - Technicznej pod hasłem „POSTĘP W TECHNOLOGIACH LUTOWANIA” WROCŁAW 2013}

\section{Wrocław, 23-25 września 2013 (poniedziałek - środa)} aula A1, bud. B-4 PWr, ul. Łukasiewicza 5

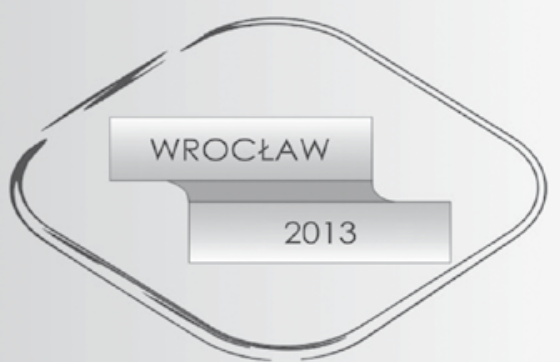

Wszystkich zainteresowanych udziałem w Konferencji prosimy o kontakt z Zakładem Spawalnictwa ITMiA Politechniki Wrocławskiej

Prof. dr hab. inż. dr h.c. Władysław Włosiński - Przewodniczący Komitetu Naukowego IV Wydział Nauk Technicznych PAN Warszawa

Prof. dr hab. inż. Andrzej Ambroziak - Sekretarz Komitetu Naukowego tel. (071) 3202148, e-mail: andrzej.ambroziak@pwr.wroc.pl

Prof. dr hab. inż. Zbigniew Mirski - Przewodniczący Komitetu Organizacyjnego tel. (071) 3202142, e-mail: zbigniew.mirski@pwr.wroc.pl

Mgr inż. Anna Woźna - Sekretarz Komitetu Organizacyjnego tel. (071) 3202074, e-mail: anna.wozna@pwr.wroc.pl

Dr inż. Tomasz Piwowarczyk - Sekretarz Komitetu Organizacyjnego tel. (071) 3204255, e-mail: tomasz.piwowarczyk@pwr.wroc.pl

Korespondencję prosimy kierować na adres:

Komitet Organizacyjny 4. Międzynarodowej Konferencji Naukowo - Technicznej „Postęp w technologiach lutowania”

Politechnika Wrocławska, Zakład Spawalnictwa ITMiA

Wybrzeże Wyspiańskiego 27 50-370 Wrocław 